\title{
ONLINE MARKETING COMMUNICATION DIRECTED TO WOMEN IN THE CAR MARKET
}

\begin{abstract}
Women are not only drivers but also account for $40 \%$ of all customers buying new cars. Development of the Internet has meant that women are now very conscious and educated customers. They spend a lot of time getting information before buying a car using mainly the Internet. The aim of the article is to identify the most common messages on websites in relation to "a car for women." The research method was the analysis of contents and the content analysis. Half of the websites contain criteria that guide women when buying a car or advice on what they should look for when choosing a car. The most common criteria considered by women when choosing a car were the appearance and operating costs (economical use). In the rankings of the criteria in the first place there was often safety and functionality (ease of parking, large trunk, adaptation for children) than appearance. It means that there is a need to pay attention to the larger variety of communication addressed to women. Stereotypical appeal in marketing communication only to the appearance and color of the car as the most important for women can result in failure.

Keywords: online marketing communication, car market, marketing to women.
\end{abstract}

\section{INTRODUCTION}

Women constitute $44 \%$ of all drivers traveling on our roads $-8,8$ million. As much as $40 \%$ of all customers purchasing new cars account for women. ${ }^{2}$ The process of buying a new car usually consists of several phases: information gathering, test drive, qualification of a purchaser, price negotiations, sales finalization. The purpose of collecting information is to get familiar and understand the car market and narrow the alternatives of purchasing choices. Development of the Internet has meant that women are now very conscious and educated customers. They spend a lot of time getting information before buying a car. This is partly due to the fact that the list of criteria to be taken into consideration is long and detailed. According to J. Cunningam and Ph. Roberts a decisionmaking by women is more complex, multi-layered and detailed due to the nature of mental and social processes. They have to know what they need themselves, but also they often have to take into account the reactions and needs of other people. ${ }^{3}$ The decision to buy a car is usually a non-routine and prudent therefore the stage of searching for information is long and based on many criteria. The main source of information on luxury

\footnotetext{
${ }^{1}$ Beata Zatwarnicka-Madura PhD, Department of Marketing, Faculty of Management, University of Technology of Rzeszow, Poland, e-mail: bezat@prz.edu.pl

${ }^{2}$ Data of Centralnej Ewidencji Pojazdów i Kierowców (CEPIK) (Central Vehicle and Driver Register) followed: Pragmatyzm i funkcjonalność, czyli samochód oczami kobiety w badaniu Alphabet Polska, https://www.alphabet.com (20.07.2016)

${ }^{3}$ J. Cunningham, P. Roberts, Zakupy na obcasach, Wydawnictwo Naukowe PWN, Warszawa 2012, pp. 234-236
} 
goods which may include cars is the Internet. ${ }^{4}$ Additionally - women search for information which it is easy to reach ${ }^{5}$. The Internet is one of the easiest source of communication to reach. In addition, cars are one of the product categories which are the most susceptible to the ROPO effect (research online, purchase offline), which means that many people are looking for accurate product information on websites before they purchase it in traditional places of sales.

The aim of the article is to identify the most common messages on websites in relation to "a car for women."

Research problems include:

- What elements the websites include, e.g. text, graphics, images, sound, animation, video?

- Who owns the websites (type of websites)?

- If the texts include information on the criteria which guide women when choosing a car?

- What criteria are mentioned in the texts as the most important for women when choosing a car, or if they are in accordance with the stereotype - women choose small cars and appearance and color are the most important selection criteria?

\section{RESEARCH METHOD}

To achieve the goal the method of analysis of contents and content analysis have been applied. Although very often these two methods are equated, but for the purpose of this article it was decided that the analysis of contents is a survey of the entire contents of the message, e.g. photographs, sounds, colors, and the content analysis is the study only of the message. The aim of the content analysis is to reduce the content of all text to the most important meanings: the most frequently occurring words, the key topics, etc. The content analysis was widespread in the 40s of the twentieth century in the United States and was used to study the communication and media. One of the promoters of this method was the American sociologist Harold Dwight Lasswell. In the same period, another American sociologist Bernard Berelson presented his own definition of content analysis, which was described as a research technique used to objective, systematic and quantitative description of overt content of the message. ${ }^{6}$

For the analysis of contents there were selected 30 sites that were the first results in the most popular search engine Google (97\% of users) appearing after the words "car for women." An analysis of content was related to the same sites, provided that they contain text. The time range of the research was the period from 24 to 26 November 2016.

\section{RESULTS}

For the analysis there were chosen 27 out of 30 websites that were the first results appearing after writing the keywords "a car for women." The analysis excluded 3 websites which contained only forums.

\footnotetext{
${ }^{4}$ Zachowania rynkowe kobiet, ed. E. Kieżel, S. Smyczka, Wydawnictwo Placet, Warszawa 2012, pp. $276-277$

5 J. Stecko, Kultura zaufania jako fundament społecznego życia etycznego [w:] Zaufanie w życiu publicznym, Ed. W. Zuziak, J. Mysona Byrska, Kraków 2014, s.163-174.

${ }^{6}$ P. Dobrodziej, https://dobrebadania.pl/analiza-tresci-ang-content-analysis/ (26.07.2016)
} 
Most sites (11) were represented by Automotive portals, 4 sites on ads of car makes, 3 -women portals women, while the others are advertisements of intermediaries, guides of bloggers and others (9).

Table 1 shows the contents of the analyzed web pages in terms of volume and percentage.

Tabela 1 . The contents of the analyzed websites (quantity and percentage)

\begin{tabular}{|l|c|c|}
\hline Elements of websites & No. of websites & $\begin{array}{c}\text { Share (in } \\
\text { \%) }\end{array}$ \\
\hline Text & 26 & 96 \\
\hline Photos, including those in intensive color & $24(21)$ & 85 \\
\hline Sound & 4 & 15 \\
\hline Video & 4 & 15 \\
\hline Animations & 3 & 11 \\
\hline
\end{tabular}

Source: Own research

Half of the websites (14) contained criteria that guide women when buying a car or advice on what they should look for when choosing a car (Tab. 2). Tabela 2. The most common criteria that guide women when choosing a car (according to the analyzed web pages)

\begin{tabular}{|l|c|}
\hline Criteria & No. of websites (14) \\
\hline appearance & 12 \\
\hline economical in use (operating costs) & 71 \\
\hline car size & 7 \\
\hline safety & 7 \\
\hline adaptation for children & 6 \\
\hline ease in parking & 6 \\
\hline largetrunk & 6 \\
\hline convenience (interior) & 5 \\
\hline colour & 5 \\
\hline reliability & 3 \\
\hline equipment & $<3$ \\
\hline modern & \\
\hline $\begin{array}{l}\text { Others (price, make, technical } \\
\text { parameters, place of purchase, standing } \\
\text { out) }\end{array}$ & \\
\hline
\end{tabular}

Source: Ownreserach 
On several of the sites analyzedthe research among women on this issue was presented. The results, however, were often contradictory.

On one website the results of research by Alphabet Poland ${ }^{7}$ (conducted during the training Female fleet at the beginning of March 2015 on a representative group of 45 women professionally connected with fleet management) were presented and were compiled with the results of market surveys by TNS Pentor and Research Institute ARC Market and Opinion.

According to TNS Pentor women, when buying a car, are driven primarily by practical considerations. More than half of the respondents most often chooses the small hatchback cars, which enable efficient movement around the city and facilitate parking on crowded streets and tight parking spaces. One third of women (32\%) opt for body of station wagon and sedan type, and only $17 \%$ choose large SUVs ${ }^{8}$.

In turn as many as $64,4 \%$ respondents of the Alphabet study pointed at SUVs as the preferred type of car, arguing their choice a comfortable position behind the wheel, plenty of space, a sense of road safety and the lack of having to worry about the kerbs. ${ }^{9}$

Regardless of the chosen career, the most important attributes of a car for women are safety and reliability (65\% of women, according to studies by Pentor and Research Institute ARC Market and Opinion, and $72 \%$ of the study participants by Alphabet Poland). The differences among the preferred characteristics of a car appear only at the next positions of the rating. In the studies by Research Institute ARC Market and Opinion $^{10}$, with the possibility of multiple choice, there were in order, the size of the car (39\%), appearance and rich equipment (by 32\%) and make/prestige (29\%). In the case of the selection of a company car (research by Alphabet Poland) in second place with 44,2\% there were the appearance and rich furnishings, and the third the economy of purchase and operation $(39,5 \%$.). In these studies, the size of the car and a make and prestige received only a few percent, but maybe respondents indicating SUV as the preferred type of car considered that these items are already included in it. ${ }^{11}$

Another web page gives the results of the research by Polish network of car service ProfiAuto in which women were asked what criteria they consider when making a decision about buying a car. The first place was taken by two parameters - the look (31\%) and technical data $(31 \%)$, next make $(22 \%)$ and price $(15 \%)$.

The message on another of the analyzed websites is "How wrong there are the men living in the belief that a woman who decides to buy a new car is guided by criteria such as color, brand, or appearance. Ladies make informed choices, they carefully analyze the technical parameters and rarely buy the car under emotions (as opposed to men). ${ }^{12}$ In the

\footnotetext{
${ }^{7}$ Alphabet Poland is one of the four largest providers of Car Fleet Management in Europe, represented in 18 countries and is currently financing a fleet of over 555,000 vehicles. The company was founded in 1997 as part of the BMW Group specializes in the leasing and fleet management. In Poland, Alphabet is currently managing a fleet of more than 12000 cars.

${ }^{8}$ Data by TNS Pentor,followed: Pragmatyzm i funkcjonalność, czyli samochód oczami kobiety w badaniu Alphabet Polska, https://www.alphabet.com (28.12.2015)

${ }^{9}$ Pragmatyzm i funkcjonalność, czyli samochód oczami kobiety w badaniu Alphabet Polska, https://www.alphabet.com (28.12.2015)

${ }^{10}$ The research was done in 2012 using a survey among 327 women at the age 30-54 years old.

${ }^{11}$ Ibid.

${ }^{12}$ Małe i eleganckie, czyli 5 samochodów dla kobiety aktywnej,
} 
next part of the message the author refers to already cited in this article studies by Research Institute ARC Market and Opinion and expert opinions.

According to the authors of the web page Deweloperskie.pl, the study of American scientists carried out jointly with the major automotive brands, show that "women are more likely than men to opt for large SUV models. They are headed primarily by safety bigger car evokes a sense of a higher comfort both as to save themselves and children who ride in the back seat." ${ }^{13}$

A survey conducted jointly by the Mobile Institute, the agency Management Beauty PR \& Marketing to Women and advertising agency Glossy Media shows that women, buying a car, analyze a lot more factors than men. ${ }^{14}$ They also have a higher rate of treatment the vehicle pragmatically, i.e., as a means to help them perform daily duties (4,14 on a scale of 1-6). According to the report, contrary to popular opinion, women come up to purchase analytically, pay attention to safety (57\%.), economy $(51 \%)$ and comfort $\left(50 \%\right.$.). ${ }^{15}$

On the next analyzed websites "on the occasion of Women's Day one decided to write a few words about the characteristics of the cars that women choose "(tab. 3). The website does not cite any research, so we are not sure how this material was made.

Tabela 3. Features of cars that women choose

\begin{tabular}{|l|l|}
\hline Feature & Description \\
\hline Colour & $\begin{array}{l}\text { Women love cars in typically feminine colors. Manufacturers know this } \\
\text { and in the automotive market there are more and more pink, purple or } \\
\text { willow-green cars. In addition, there are also multicolor vehicles in which } \\
\text { colors such as, e.g. red and black combine to form an interesting } \\
\text { composition. }\end{array}$ \\
\hline Size & $\begin{array}{l}\text { Women usually prefer to drive small, urban car. For them, the most } \\
\text { important is the convenience of getting to work or shopping. For women } \\
\text { with children the best cars are those which fit child seats and all necessary } \\
\text { stuff for family trips. }\end{array}$ \\
\hline Comfort, safety & $\begin{array}{l}\text { Regardless of what color the car is and what is its size, women put } \\
\text { primarily on ease of operation, reliability and comfort and safety. Thus, a } \\
\text { large part of women thatis able to choose any car, puts on a comfortable } \\
\text { family car, not a sports car. }\end{array}$ \\
\hline Gadgets & $\begin{array}{l}\text { Another thing that women pay attention tois additional equipment that } \\
\text { helps in the safe use of the car. Thus, additional spoilers, light or the } \\
\text { sunroof do not make much of an impression on them. Women choose the } \\
\text { car with comfortable seats, a practical upholstery and a large trunk. }\end{array}$ \\
\hline
\end{tabular}

Source: Samochód dla kobiety, http://wigmet.pl/blog/samochod-dla-kobiety/

http://deluxe.trojmiasto.pl/Male-i-eleganckie-czyli-5-samochodow-dla-kobiety-aktywnej-

n73724.html (26.07.2016)

${ }^{13}$ Nowoczesność i elegancja, czyli idealny samochód dla kobiety,

http://okazjedeweloperskie.pl/Nowoczesnosc-i-elegancja-czyli-idealny-samochod-dla-kobiety.html (28.12.2014)

${ }^{14} \mathrm{http}: / /$ ceo.com.pl/plec-ma-coraz-mniejszy-wplyw-na-preferencje-zakupowe-tworcy-reklam-nienadazaja-za-zmianami-i-wciaz-przewazaja-stereotypy-21515 (29.12.2015)

${ }^{15}$ Ibid. 


\section{DISCUSSION}

The research helped to answer the research questions:

1. Almost all web pages contain text and pictures. The most intense colors of photos of cars presented confirm the stereotypical approach to women.

2. Among the analyzed sites there were the most automotive portals.

3. Half of the websites contained criteria that guide women when buying a car.

4. The most common criteria considered by women when choosing a car were the appearance and operating costs (economical in use), which on the one hand confirms the stereotype (appearance), on the other hand it indicates that the operating costs are equally important. In the rankings of the criteria in the first place often appeared safety and functionality (ease of parking, large trunk, adapted for children) than appearance. Women more likely opt for small cars, but the most important selection criteria are appearance and color, as a stereotypically considered.

It is difficult to find the source of research directly related to the criteria influencing the choice of cars by women. However, there were done some research on the differences between women and men in the purchase decision-making process.

The consumption analysis from the perspective of gender is studied by Fischer and Arnold with regard to their differences in various contexts and product preferences. ${ }^{16}$ Putrevu analyzes the differences in information processing between the sexes and suggests that men and women process information about a product differently according to the role that product has on society and the capacity that it has in expressing masculine or feminine characteristics in that culture. ${ }^{17}$ The results contradict the studies by Haas that describe men as more analytical and logical in processing information and women as more subjective and intuitive. ${ }^{18}$ Putrevu also suggests that product advertisement aimed at the male public should endorse specific attributes of the product while advertisements aimed at women should use more extensive information like the product's category. The research by Castro and others shows, that in spite of that, the meaning that the product possesses for women has positioned them as more analytical and less sentimental than men when purchasing avehicle. ${ }^{19}$

Because of the contradictory results, both those carried out by the author in the Internet and the cited research results of various authors, there is a need for further investigation. These studies should focus on the differences in making purchase decisions based on gender and a type of product.

However, according to research conducted by the author of the article, one can draw some conclusions for managers dealing with the automotive industry. There is a need to pay attention to the larger variety of communication addressed to women. Stereotypical

\footnotetext{
${ }^{16}$ E. Fischer, S. J. Arnold, Sex, Gender Identity, Gender Role Attitudes, and Consumer Behavior. Psychology \& Marketing, v. 11, n. 2, p. 163-182, 1994.

${ }^{17}$ B. Putrevu, Exploring the origins and information processing differences between men and women: Implications for advertisers. Academy of Marketing Science Review, 2001.

Disponívelem: <http://www.vancouver.wsu.edu/amsrev/theory/putrevu10-01.html>. Acesso em: 18 fev. 2014.

${ }^{18}$ A. Haas, Male and female spoken language differences: stereotypes and evidence. Psychological Bulletinv. 86, p. 616-626, 1979.

${ }^{19}$ B.G.A. Castro, C.V. Torres, T.G. Nascimento, G. Demo, Are Men More Rational than Women when Purchasing Cars, "Brazilian Business Review" 2015, v.12, n.6, pp. $72-99$
} 
appeal in marketing communication only to the appearance and color of the car as the most important for women can result in failure.

\section{KOMUNIKACJA MARKETINGOWA ONLINE SKIEROWANA DO KOBIET} NA RYNKU SAMOCHODÓW OSOBOWYCH

Kobiety są nie tylko w dużej mierze kierowcami ale też stanowią $40 \%$ wszystkich klientów kupujących nowe samochody. Rozwój Internetu spowodował, że kobiety są obecnie bardzo świadomymi i wyedukowanymi klientami. Poświęcają dużo czasu na pozyskiwanie informacji przed zakupem samochodu korzystając przede wszystkim z Internetu. Celem artykułu jest identyfikacja najczęściej występujących przekazów na stronach internetowych w odniesieniu do "samochodu dla kobiet". Metodą badawczą była analizy zawartości i analizy treści. Połowa stron internetowych zawierała kryteria, którymi kierują się kobiety przy zakupie samochodu osobowego lub porady, na co powinny zwracać uwagę przy wyborze samochodu. Najczęściej występującymi kryteriami branymi pod uwagę przez kobiety przy wyborze samochodu były wygląd i koszty eksploatacji (ekonomiczny w użytkowaniu). W rankingach kryteriów na pierwszym miejscu częściej pojawiało się bezpieczeństwo i funkcjonalność (łatwość parkowania, duży bagażnik, przystosowanie dla dzieci) niż wygląd. Wynika $\mathrm{z}$ tego, że istnieje konieczność zwrócenia uwagi na większe zróżnicowanie przekazu adresowanego do kobiet. Stereotypowe odwoływanie się w komunikacji marketingowej tylko do wyglądu i koloru samochodu jako najistotniejszych dla kobiet może skutkować porażką.

Słowa kluczowe: komunikacja marketingowa on line, rynek samochodowy, marketing dla kobiet.

\section{REFERENCES}

[1] Castro B.G.A., Torres C.V., Nascimento T.G., Demo G., Are Men More Rational than Women when Purchasing Cars, "Brazilian Business Review" 2015, v.12, n.6

[2] Cunningham J., Roberts P., Zakupy na obcasach, Wydawnictwo Naukowe PWN, Warszawa 2012

[3] Disponívelem: <http://www.vancouver.wsu.edu/amsrev/theory/putrevu1001.html>. Acesso em: 18 fev. 2014.

[4] Dobrodziej P., https://dobrebadania.pl/analiza-tresci-ang-content-analysis/

[5] Fischer E., Arnold S. J., Sex, Gender Identity, Gender Role Attitudes, and Consumer Behavior. Psychology \& Marketing, v. 11, n. 2, 1994.

[6] Haas A., Male and female spoken language differences: stereotypes and evidence. Psychological Bulletinv. 86, 1979.

[7] Małe i eleganckie, czyli 5 samochodów dla kobiety aktywnej, http://deluxe.trojmiasto.pl/Male-i-eleganckie-czyli-5-samochodow-dlakobiety-aktywnej-n73724.html

[8] Nowoczesność i elegancja, czyli idealny samochód dla kobiety, http://okazjedeweloperskie.pl/Nowoczesnosc-i-elegancja-czyli-idealnysamochod-dla-kobiety.html http://ceo.com.pl/plec-ma-coraz-mniejszy-wplyw-na-preferencje-zakupowetworcy-reklam-nie-nadazaja-za-zmianami-i-wciaz-przewazaja-stereotypy21515 
[9] Putrevu B., Exploring the origins and information processing differences between men and women: Implications for advertisers. Academy of Marketing Science Review, 2001.

[10] Pragmatyzm i funkcjonalność, czyli samochód oczami kobiety w badaniu Alphabet Polska, https://www.alphabet.com

[11] Stecko J., Kultura zaufania jako fundament społecznego życia etycznego [w:] Zaufanie w życiu publicznym, Ed. W. Zuziak, J. Mysona Byrska, Kraków 2014.

[12]Zachowania rynkowe kobiet, ed. E. Kieżel, S. Smyczka, Wydawnictwo Placet, Warszawa 2012

DOI:10.7862/rz.2016.hss.56

Przesłano do redakcji: wrzesień 2016

Przyjęto do druku: grudzień 2016 